\title{
Dopamine Receptor Antagonists Fail to Prevent Induction of Cocaine Sensitization
}

Francis J. White, Ph.D., Amit Joshi, M.D., Timothy E. Koeltzow, B.A., and Xiu-Ti Hu, M.D., Ph.D.

We investigated the ability of dopamine $D_{1}$ and $D_{2}$ class receptor antagonists to prevent the induction of behavioral sensitization to cocaine. The $D_{2}$ receptor antagonist eticlopride failed to prevent the induction of cocaine sensitization. An intermediate dose of the $D_{1}$ receptor antagonist SCH $23390(0.1 \mathrm{mg} / \mathrm{kg})$ appeared to prevent the induction of cocaine sensitization when tested after 3 days of withdrawal, but sensitization was clearly evident after 10 days of withdrawal. High doses of SCH 23390 alone produced supersensitivity to the behavioral effects of cocaine and to the inhibitory effects of $D_{1}$ receptor agonists on

KEY WORDS: Cocaine; Behavioral sensitization; Dopamine $D_{1}$ receptors; Dopamine $D_{2}$ receptors; Nucleus accumbens; Ventral tegmental area

Repeated administration of cocaine produces sensitization (reverse-tolerance) to its locomotor stimulant effects (for reviews, see Post 1980; Post et al. 1992; Kalivas 1995). The mechanisms responsible for cocaine sensitization are the subject of intense investigation because of the possible relevance of such plasticity to development of psychomotor stimulant-induced psychosis and to mechanisms of drug craving and addiction (for reviews, see Post and Contel 1983; Robinson and Berridge 1993). Given that the primary molecular targets of cocaine in the nervous system are the transporter proteins

From the Neuropsychopharmacology Laboratory, Department of Neuroscience, Finch University of Health Sciences, Chicago Medical School, North Chicago, Illinois.

Address correspondence to: Francis J. White, Ph.D., Neuropsychopharmacology Laboratory, Department of Neuroscience, Finch University of Health Sciences, Chicago Medical School, 3333 Green Bay Road, North Chicago, IL 60064-3095.

Received April 23, 1997; revised June 5, 1997; accepted June 10, 1997. nucleus accumbens neurons. Co-administration of eticlopride and SCH 23390 also failed to prevent the induction of cocaine sensitization. SCH 23390, but not eticlopride, prevented the expression of cocaine sensitization. We conclude that dopamine receptors are either not involved in the induction of cocaine sensitization or that redundant mechanisms exist to produce the same neuroadaptations. [Neuropsychopharmacology 18:2640, 1998] (C) 1998 American College of

Neuropsychopharmacology. Published by Elsevier Science Inc.

responsible for removal of monoamine neurotransmitters from synapses (Ritz et al. 1987), it is not surprising that the neural systems impacted by these messengers have been scrutinized for mechanisms of behavioral sensitization. In particular, dopamine (DA) neurons and their primary targets within the mesocorticolimbic system have been implicated in the locomotor stimulant and positive reinforcing properties of cocaine (for reviews, see Wise and Bozarth 1987; Koob 1992), and neuroadaptations within this system are thought to be related to the development and expression of cocaine sensitization (for reviews, see Kalivas 1995; White et al. 1995a).

Studies with DA receptor antagonists have consistently implicated DA receptors in the expression of cocaine sensitization. Antagonists with selectivity for either the $\mathrm{D}_{1}\left(\mathrm{D}_{1}, \mathrm{D}_{5}\right)$ or $\mathrm{D}_{2}$ class $\left(\mathrm{D}_{2}, \mathrm{D}_{3}, \mathrm{D}_{4}\right)$ of DA receptors (hereafter simply called $\mathrm{D}_{1}$ and $\mathrm{D}_{2}$ ) can prevent the acute locomotor stimulatory effects of cocaine and the gradual increase in those effects during the repeated treatment regimen (McCreary and Marsden 1993; Tella 1994; Mattingly et al. 1994, 1996; Kuribara 1995b). However, the evidence for DA receptor involvement in the induction (also referred to as development or acquisi- 
tion) of cocaine sensitization is sparse. This profile differs from that observed with the other major psychomotor stimulant, amphetamine, because there is widespread support for an involvement of both $D_{1}$ and $D_{2}$ receptors in both the induction and expression of amphetamine sensitization (Vezina and Stewart 1989; Stewart and Badiani 1993; Hamamura et al. 1991; Kuribara and Uchihashi 1994; Kuribara 1995c). Unfortunately, many authors are not careful in making necessary distinctions between: (1) cocaine and amphetamine sensitization, (2) induction and expression of sensitization, or (3) conditioned activity and behavioral sensitization. For this reason, there is considerable confusion in the literature as to what has actually been demonstrated experimentally.

From a historical perspective, Beninger and Herz (1986) first showed that pimozide, an antagonist at $D_{2}$ receptors and a blocker of L-type calcium channels, prevents development but not expression of classically conditioned locomotor activity induced by explicit pairings of cocaine and a test environment, but demonstrated in the absence of cocaine. Presumably, calcium channel blockade was responsible, since the L-type calcium channel antagonist nimodipine, but not the $\mathrm{D}_{2}$ receptor antagonist haloperidol also produced this effect (Reimer and Martin-Iverson 1994). Subsequently, Weiss et al. (1989) found that haloperidol prevented development, but not expression, of enhanced cocaine-induced locomotion after a single previous cocaine administration. This paradigm has been referred to as "one-shot" sensitization and is unique in that it is entirely contextdependent, i.e., sensitization is only observed in the environment in which the first cocaine injection was given. Subsequent studies have indicated that this form of sensitization is prevented by several $D_{2}$ receptorselective antagonists (raclopride, sulpiride) as well as the $\mathrm{D}_{1}$ receptor-selective antagonist SCH 23390 (Fontana et al. 1993).

When cocaine sensitization is studied with repeated administration paradigms (as opposed to one-shot), a different profile of effects is observed with DA receptor antagonists. SCH 23390 prevents expression of this form of cocaine sensitization (McCreary and Marsden 1993; Martin-Iverson and Reimer 1994; Tella 1994), whereas the results with haloperidol have been equivocal (Martin-Iverson and Reimer 1994; Tella 1994). Haloperidol appears to attenuate induction of repeated administration forms of cocaine sensitization but only when the context-dependency of behavioral sensitization is maximized (Reimer and Martin-Iverson 1994; Mattingly et al. 1996). Perhaps the most surprising result from such studies is that, unlike amphetamine sensitization, $D_{1}$ receptor antagonists have consistently been found ineffective in preventing the induction of cocaine sensitization-even in highly context-dependent paradigms (Mattingly et al. 1994, 1996; Kuribara 1995b). These results are critical for our understanding of mechanisms involved in the induction of sensitization. Indeed, the most widely popularized hypothesis states that $D_{1}$ receptor stimulation within the ventral tegmental area is a necessary condition ("trigger") for the induction of psychomotor stimulant sensitization (Stewart and Vezina 1989; Kalivas and Stewart 1991; Kalivas 1995; Bjijou et al. 1996; Vezina 1996). For this reason, we have revisited the issue of DA receptor involvement in cocaine sensitization. We have examined the ability of the selective $\mathrm{D}_{1}$ receptor antagonist $\mathrm{SCH}$ 23390 and the selective $D_{2}$ receptor antagonist eticlopride, administered separately or together, to alter the induction of locomotor sensitization to repeated injections of cocaine. We intentionally chose a treatment paradigm that minimizes the context dependency of sensitization. We studied a variety of doses and withdrawal intervals and found that DA receptor antagonists failed to prevent the induction of cocaine sensitization and that SCH 23390, but not eticlopride, prevented expression of cocaine sensitization.

\section{MATERIALS AND METHODS}

\section{Animals}

Male Sprague-Dawley rats (Harlan, Indianapolis, IN) weighing 175-200 $\mathrm{g}$ at the beginning of the experiment were housed in groups of 2-3 in standard "shoe-box" type plastic cages. Food and water were freely available at all times. The vivarium was maintained at constant temperature and humidity, with a 12-h light:dark cycle (lights on at 7:00 A.M.). Animals were allowed 4-7 days to acclimate to the vivarium before the beginning of experiments. During this time, they were handled and weighed daily.

\section{Design and Procedure}

We used many different antagonist treatment regimens in our attempts to prevent the induction of cocaine sensitization, but the basic cocaine sensitization regimen was identical in every case. The rats received five daily injections of cocaine $\mathrm{HCl}(15.0 \mathrm{mg} / \mathrm{kg}$, IP), all of which occurred in the home cages. Each rat in a cage received the same treatment. Sensitization was tested at either a 3- or 10-day withdrawal time using a test injection of 7.5 $\mathrm{mg} / \mathrm{kg}$ (IP), which was given in the test environment (below) after a 30-min habituation period. We have observed that this low challenge dose is just at the threshold for induction of significant ambulation in control rats (Henry and White 1995) and thus provides excellent discrimination between sensitized and nonsensitized rats. In some experiments, additional tests for expression of sensitization were conducted on day 12 of withdrawal. Direct observation for the presence of stereotyped behaviors was not used in our studies for two 
reasons: (1) our previous work (Henry and White 1995) has demonstrated that horizontal locomotor activity increases linearly within the dose range of 5.0 to $40.0 \mathrm{mg} /$ $\mathrm{kg}$, even with the onset of repetitive downward sniffing and head-bobbing at doses of 20.0 and $40.0 \mathrm{mg} / \mathrm{kg}$; and (2) we intentionally chose a challenge dose of cocaine that fails to elicit stereotyped behavior even in sensitized rats.

We first determined the ability of various doses of the $\mathrm{D}_{1}$ receptor antagonist SCH $23390(0.05,0.1$ and 0.5 $\mathrm{mg} / \mathrm{kg}, \mathrm{IP})$ and the $\mathrm{D}_{2}$ receptor antagonist eticlopride $(0.1$ and $0.5 \mathrm{mg} / \mathrm{kg}, \mathrm{IP})$ to prevent the acute locomotor stimulant effects of cocaine, when administered $15 \mathrm{~min}$ before cocaine. We then used those doses in our attempts to prevent cocaine sensitization. On each treatment day, the antagonist was administered $15 \mathrm{~min}$ before cocaine or saline $(1.0 \mathrm{ml} / \mathrm{kg}$, IP). Additional groups received combined injections of SCH 23390 and eticlopride, as a cocktail, before either cocaine or saline. The two dose combinations were $0.05 \mathrm{mg} / \mathrm{kg} \mathrm{SCH} 23390+0.1 \mathrm{mg} /$ $\mathrm{kg}$ eticlopride and $0.1 \mathrm{mg} / \mathrm{kg} \mathrm{SCH} 23390+0.5 \mathrm{mg} / \mathrm{kg}$ eticlopride. Control groups received either two injections of saline or an injection of saline $15 \mathrm{~min}$ before cocaine. Separate groups of rats were tested at the 3- and 10-day withdrawal times. Because of the large number of test groups, these studies were conducted over a period of many months. Thus, several control groups were tested during the course of the study.

SCH $23390(0.1 \mathrm{mg} / \mathrm{kg})$ was also tested for its ability to prevent possible adaptations occurring during the withdrawal from repeated cocaine treatment (see Results). For these experiments, SCH 23390 or saline injections began on the first day of withdrawal and proceeded for 4 days; no cocaine injections were given. After a washout period of 7 days, rats were tested for sensitization using a challenge dose of $7.5 \mathrm{mg} / \mathrm{kg}$, as above.

To test the ability of $D_{1}$ and $D_{2}$ receptor antagonists to prevent the expression of sensitization, sensitized rats from the 10-day withdrawal saline + cocaine groups were divided into two groups, one of which received a test with saline + cocaine and one of which received the combination of either SCH $23390(0.1 \mathrm{mg} / \mathrm{kg})$ or eticlopride $(0.5 \mathrm{mg} / \mathrm{kg})$ with cocaine. Cocaine $\mathrm{HCl}$ was obtained from Sigma and was dissolved in $0.9 \% \mathrm{NaCl}$. All other compounds were purchased from Research Biochemicals Inc. SCH $23390 \mathrm{HCl}$ and eticlopride $\mathrm{HCl}$ were dissolved in $0.9 \% \mathrm{NaCl}$. All doses refer to the salts.

\section{Apparatus}

Locomotion was monitored in 12 photobeam chambers (San Diego Instruments) located in a separate testing room within the vivarium. Each chamber was $50 \times 30$ $\mathrm{cm}$ with 3 photocells (separated by $10.5 \mathrm{~cm}$ ) located lengthwise, $3.5 \mathrm{~cm}$ above the floor. One rat was placed in each chamber and its activity was measured automatically using customized computer software that provides user-defined intervals of total photobeam interruptions as well as ambulation counts. Ambulation is defined as breaking of consecutive photobeams and separates true horizontal locomotion from repetitive interruptions of the same photobeam produced by stereotyped movements such as rearing, licking, and head-bobbing. On test days, rats were habituated to the photobeam chambers for $30 \mathrm{~min}$ before cocaine injection. Activity was measured for $1 \mathrm{~h}$ after cocaine injections.

\section{Single-Cell Recording}

Because our behavioral results sometimes suggested that repeated administration of the $\mathrm{D}_{1}$ receptor antagonist SCH 23390 had resulted in receptor supersensitivity, we used extracellular single-cell recordings from nucleus accumbens neurons to test this possibility. Separate groups of rats were used for the electrophysiological tests, which used standard techniques as detailed previously (e.g., see $\mathrm{Hu}$ and White 1994). Briefly, rats were anesthetized with chloral hydrate $(400 \mathrm{mg} / \mathrm{kg} \mathrm{IP})$ and mounted in a stereotaxic apparatus. A tail vein was catheterized for additional injections of chloral hydrate (50 mg/ $\mathrm{kg}, \mathrm{IV}$ ) as needed to maintain anesthesia. The scalp was opened and retracted, and a burr hole was drilled in the skull over the nucleus accumbens (10.2$10.4 \mathrm{~mm}$ anterior to lambda, $0.9-1.5 \mathrm{~mm}$ lateral to the midline suture).

Five-barrel micropipettes were used to record and to apply substances with microiontophoresis. The center barrel was filled with $2 \mathrm{~mol} / \mathrm{L} \mathrm{NaCl}$ saturated with $1 \%$ (w/v) Fast Green dye (impedance 1-3 M 2 ) and was used for recording. One side barrel contained $4 \mathrm{~mol} / \mathrm{L}$ $\mathrm{NaCl}$ for automatic current balancing. Another side barrel contained L-glutamate monosodium salt (100 $\mathrm{mmol} / \mathrm{L}$ in $50 \mathrm{mmol} / \mathrm{L} \mathrm{NaCl}, \mathrm{pH} 8$, Sigma) to activate quiescent neurons. The final two barrels contained the $\mathrm{D}_{1}$ receptor agonist SKF 38393 and the $\mathrm{D}_{2}$ receptor agonist quinpirole (both at $10 \mathrm{mmol} / \mathrm{L}$ in $150 \mathrm{mmol} / \mathrm{L}$ $\mathrm{NaCl}, \mathrm{pH} 4$, Research Biochemicals, Inc.). The impedance of the side barrel was typically $15-50 \mathrm{M} \Omega$. Retaining currents (8-10 nA) were used to minimize passive diffusion. Electrodes were lowered to $6.0 \mathrm{~mm}$ below the cortical surface and recordings were obtained from there to $7.5 \mathrm{~mm}$ using a hydraulic microdrive to move the electrode. To identify quiescent neurons, glutamate was ejected (10-20 nA) during electrode descent. When a neuron was identified, a pulse procedure of $30 \mathrm{~s}$ on $/ 40 \mathrm{~s}$ off was used to apply glutamate. A glutamate current sufficient to produce a firing rate of 4-6 spikes/s was determined for each neuron. DA agonists were then applied continuously beginning at $1 \mathrm{nA}$ with the current doubled every $2 \mathrm{~min}$. Drug effects were compared to the pre-drug glutamate-induced "baseline" activity. A total of 2-4 neurons were recorded from each rat. At the end of the experiment, the last neuron was marked with Fast 
Green dye, which was subsequently localized on $50 \mu \mathrm{m}$ slices using routine histological methods.

\section{Data Analysis}

Results from behavioral experiments were analyzed either with Student's $t$-tests or with analysis of variance (ANOVA) followed by Tukey's test to make various pairwise comparisons or with Dunnett's test to compare treatment groups to control groups. In some cases, the data failed to meet assumptions of normal distribution or equal variance. When this occurred, a Kruskal-Wallis ANOVA on ranks was used followed by Dunn's test for pairwise comparisons. Electrophysiological data were analyzed using a two way ANOVA with repeated measures for current, followed by Dunnett's test. All analyses were conducted on a 586-based personal computer using SigmaStat ${ }^{\circledR}$ software (Jandel Scientific).

\section{RESULTS}

\section{Repeated Cocaine Administration Produced Persistent Behavioral Sensitization}

Repeated administration of cocaine produced marked behavioral sensitization which was evident after both 3- and 10-day withdrawal periods (Figure 1). In this experiment, the same rats were tested at the two different withdrawal times. The enhanced behavior of the cocaine-treated group was evident in both the ambulation and total counts, although the difference in ambulation counts was greater. For this reason, in all subsequent experiments, only the ambulation results are presented. The temporal pattern of activity shown in Figure 1 was also observed in all subsequent experiments; in no case did antagonist pretreatment alter the time course of behavioral activation; accordingly, time course results are not presented for subsequent experiments.
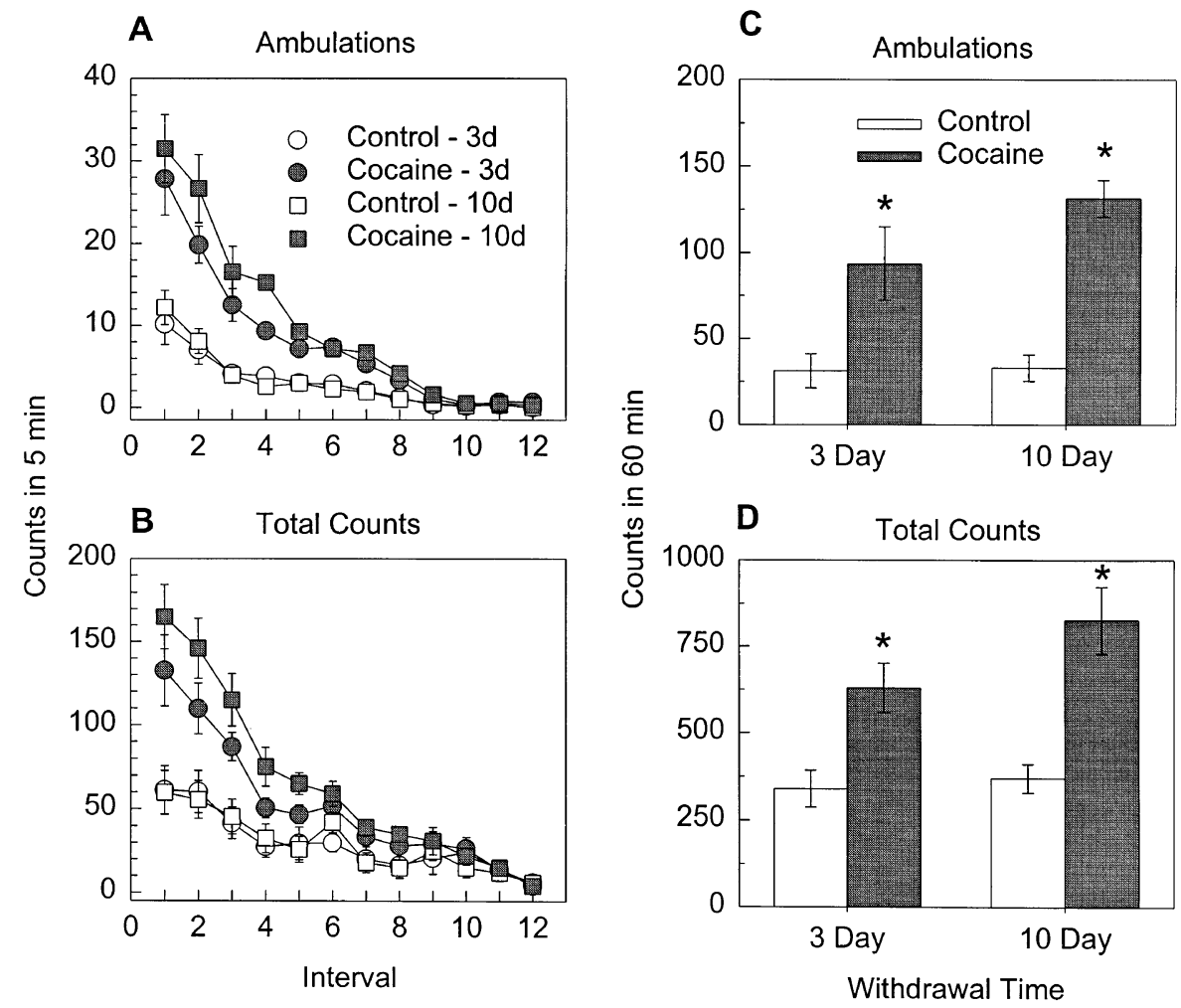

Figure 1. Repeated cocaine administration produced behavioral sensitization. (A): Time course of cocaine-induced ambulatory activity in control and cocaine-pretreated rats tested either 3 (3d) or 10 days (10d) after the last injection of the sensitization regimen. Each interval is $5 \mathrm{~min}$ in duration. Five daily injections of cocaine $(15.0 \mathrm{mg} / \mathrm{kg})$ produced significantly greater ambulatory activity in response to a challenge injection of cocaine $(7.5 \mathrm{mg} / \mathrm{kg})$ after withdrawal periods of either 3 days $\left(t_{20}=\right.$ $3.07, p=.006, n=11$ /group) or 10 days $\left(t_{22}=6.17, p<.001, n=12\right.$ /group) as shown in panel (C) which indicates the total number of ambulations summed over the 125 -min intervals. (B): Time course of cocaine-induced total activity counts in control and cocaine-pretreated rats tested either 3 or 10 days after the last injection of the sensitization regimen. Sensitization was also evident in the total number of photobeam interruptions after either three days $\left(t_{20}=3.26, p=.004\right)$ or 10 days $\left(t_{22}=\right.$ $5.08, p<.0001$ ) of withdrawal, as shown in panel (D) which indicates the total number of counts summed over the 125 -min intervals. 


\section{The $\mathrm{D}_{2}$ Receptor Antagonist Eticlopride Failed to Prevent Cocaine Sensitization}

Pretreatment with eticlopride before each of the five daily cocaine injections failed to prevent the induction

\section{D2 Receptors and Induction of Cocaine Sensitization}

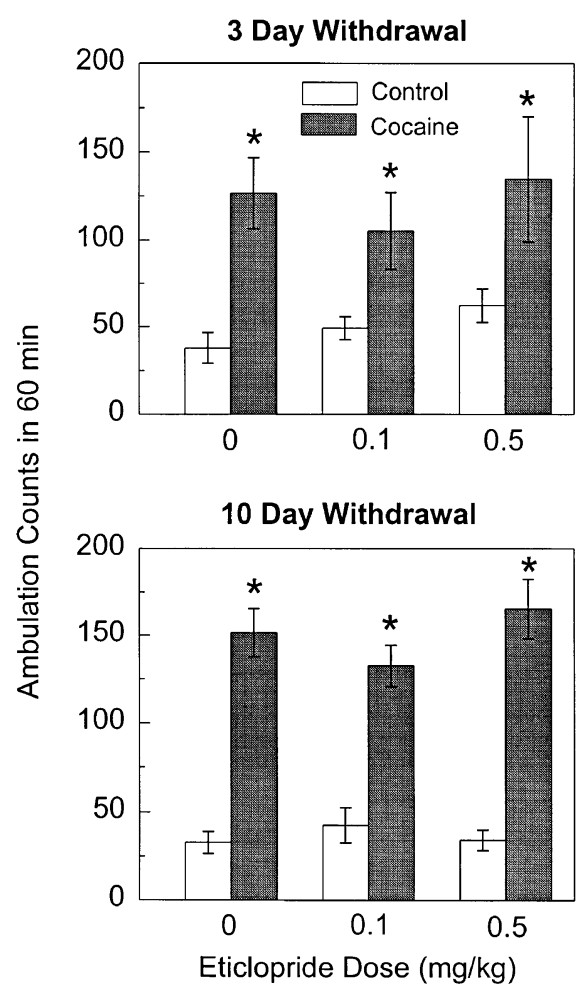

Figure 2. The $\mathrm{D}_{2}$ receptor-selective antagonist eticlopride failed to prevent the induction of cocaine sensitization. Enhanced ambulation was evident in the cocaine pretreated rats during a challenge with $7.5 \mathrm{mg} / \mathrm{kg}$ of cocaine after both 3 days (top panel) and 10 days (bottom panel) of withdrawal. A Kruskal-Wallis one way ANOVA on Ranks (normality assumption failed) revealed a significant groups effect $\left(\mathrm{H}_{5}=\right.$ $35.4, p<.001, n=11$ for all groups except the two $0.5 \mathrm{mg} / \mathrm{kg}$ eticlopride groups in which $n=12$ ); pairwise comparisons using Dunn's method revealed that each eticlopride + cocaine group was significantly greater than its corresponding eticlopride + saline control group $(p<0.05)$, that none of the eticlopride + saline groups differed from one another, and that none of the eticlopride + cocaine groups differed from one another. ANOVA on the data from the 10-day withdrawal revealed a significant groups effect $\left(F_{5,65}=18.73\right.$, $p<.001, n=11$ for saline control ( $0 \mathrm{mg} / \mathrm{kg}$ eticlopride) groups, 12 for $0.1 \mathrm{mg} / \mathrm{kg}$ eticlopride groups, and 10 for 0.5 $\mathrm{mg} / \mathrm{kg}$ eticlopride groups); post-hoc comparisons indicated that each eticlopride + cocaine group differed significantly from its corresponding control group $\left({ }^{*} p<.05\right)$, that none of the eticlopride + saline groups differed from one another, and that none of the eticlopride + cocaine groups differed from one another. of cocaine behavioral sensitization in groups of rats tested either at 3 or 10 days of withdrawal (Figure 2). The lack of effect cannot be attributed to insufficient doses because both doses chosen for study were sufficient to block the acute psychomotor stimulant effects of cocaine (Figure 3). We also tested the $0.5 \mathrm{mg} / \mathrm{kg}$ dose for its ability to prevent the expression of sensitization. This test was conducted on the saline + cocaine rats that had shown sensitization on the day 10 challenge (see Figure 2). On day 12, these 11 rats were split into two groups; one received saline + cocaine $(n=5)$ and the other received eticlopride + cocaine $(n=6)$. This relatively high dose of eticlopride failed to prevent the expression of sensitized locomotion (Figure 3 , inset).

\section{The $\mathrm{D}_{1}$ Receptor Antagonist SCH 23390 Failed to Prevent the Induction of Cocaine Sensitization}

Pretreatment with SCH 23390 before each of the five daily cocaine injections failed to prevent the induction of sensitization to cocaine, although the $0.1 \mathrm{mg} / \mathrm{kg}$ dose appeared to do so when rats were tested at the three day withdrawal time (Figure 4). When we focus on the

\section{D2 Receptors and Expression of Cocaine-Induced Locomotion}

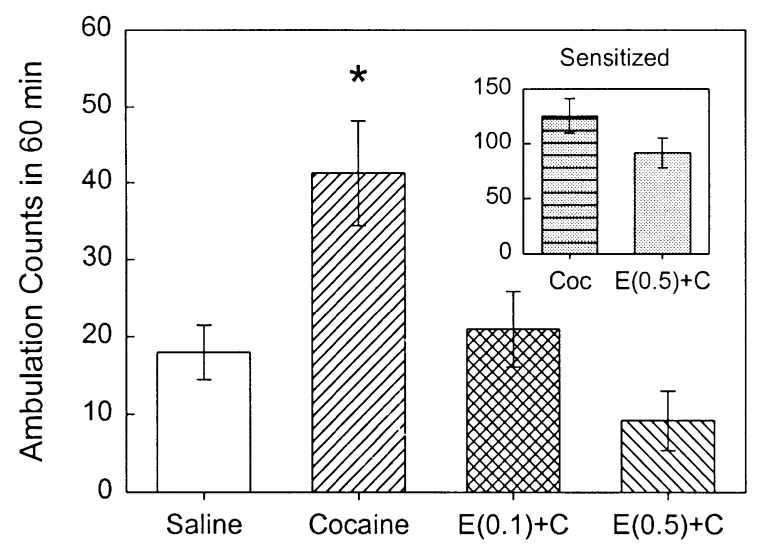

Figure 3. The $\mathrm{D}_{2}$ receptor-selective antagonist eticlopride prevented the acute locomotor stimulant effects of cocaine, but failed to prevent expression of sensitized locomotion after repeated cocaine administration. Acute administration of cocaine $(7.5 \mathrm{mg} / \mathrm{kg})$ produced a doubling of locomotor activity as compared to the saline control group. Both doses of eticlopride (E, 0.1 and $0.5 \mathrm{mg} / \mathrm{kg}$ ) prevented the locomotor stimulant effect of acute cocaine $(\mathrm{C})$. ANOVA indicated a significant groups effect $\left(F_{3,23}=10.17, p<.001, n=6 /\right.$ group) and paired comparisons indicated that only the cocaine group differed from saline $\left({ }^{*} p<.05\right)$. Inset: In rats that were sensitized to cocaine (coc), eticlopride $(0.5 \mathrm{mg} / \mathrm{kg})$ failed to prevent the sensitized response $\left(t_{9}=1.46, p=.18\right.$, $n=5$ for saline + cocaine and 6 for eticlopride + cocaine). 


\section{D1 Receptors and Induction of Cocaine Sensitization}

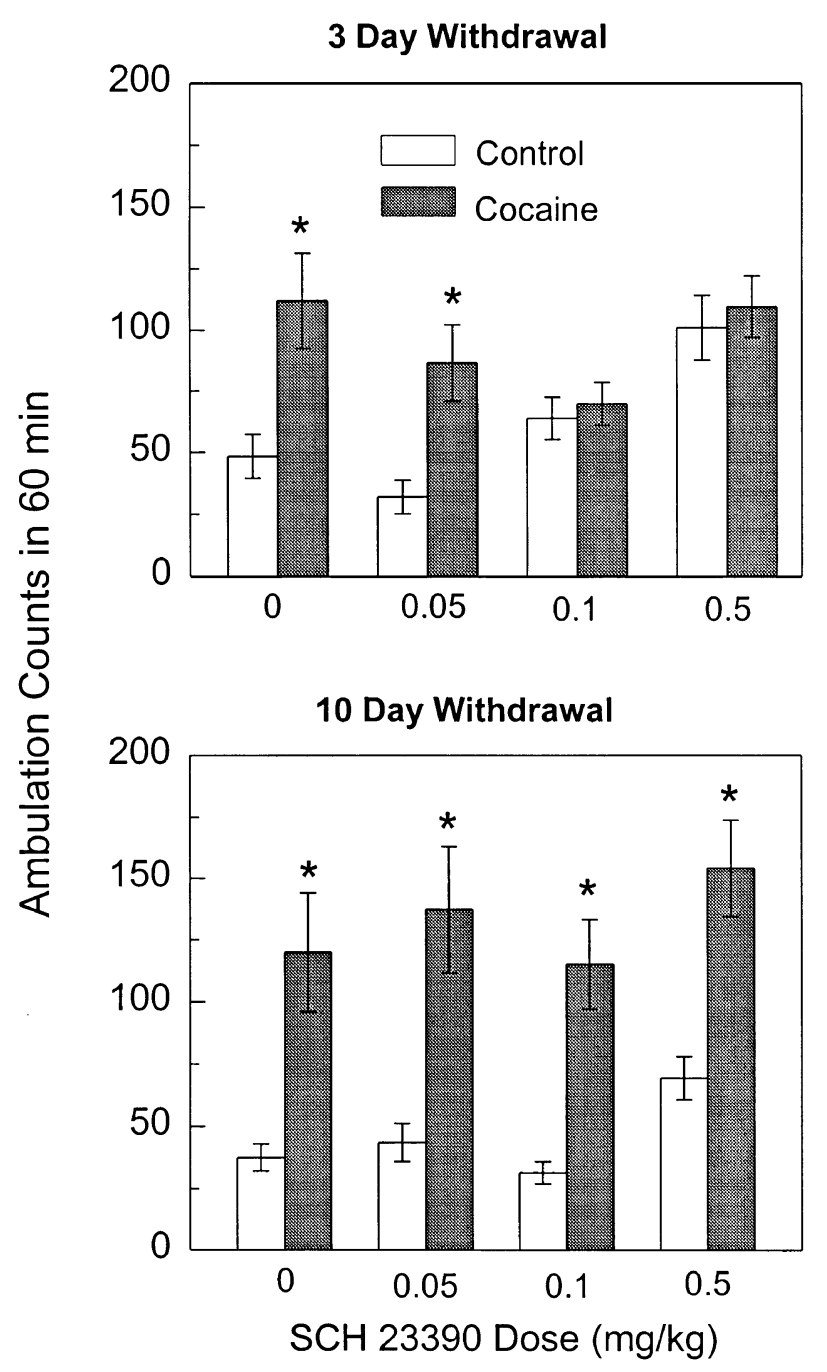

Figure 4. The $\mathrm{D}_{1}$ receptor-selective antagonist SCH 23390 failed to prevent the induction of cocaine sensitization. Top panel: Levels of ambulation were enhanced (relative to the respective SCH 23390 + saline groups) in the group of rats that received repeated cocaine in combination with the 0.05 $\mathrm{mg} / \mathrm{kg}$ dose of SCH 23390, but not the 0.1 or the $0.5 \mathrm{mg} / \mathrm{kg}$ dose, during a challenge with $7.5 \mathrm{mg} / \mathrm{kg}$ of cocaine after 3 days of withdrawal. Note that the highest dose of $\mathrm{SCH}$ $23390(0.5 \mathrm{mg} / \mathrm{kg})$ caused clear supersensitivity to cocaine as evidenced by the increased behavioral effect in the $\mathrm{SCH}$ 23390 + saline (control) group, and that in the intermediate dose groups $(0.1 \mathrm{mg} / \mathrm{kg})$ both the control and cocaine groups exhibited intermediate levels of ambulation. ANOVA revealed a significant groups effect $\left(F_{7,92}=6.734\right.$, $p<.001, n=12$ except for the saline + cocaine group and the two $0.5 \mathrm{mg} / \mathrm{kg}$ SCH 23390 groups where $n=11$ ). Paired comparisons indicated that the 0 and $0.05 \mathrm{mg} / \mathrm{kg} \mathrm{SCH}$ $23390+$ cocaine groups were significantly greater than their respective controls $\left({ }^{*} p<.05\right)$, and that both the $0.5 \mathrm{mg} / \mathrm{kg}$ SCH 23390 + saline and the $0.5 \mathrm{mg} / \mathrm{kg} \mathrm{SCH} 23390+$ cocaine groups were greater than the saline + saline group (far left results from the 3-day withdrawal experiment (Figure 4 , top panel), it is obvious that at the two higher doses of SCH $23390(0.1$ and $0.5 \mathrm{mg} / \mathrm{kg})$, the activity of the SCH 23390 + saline groups was not significantly different from the SCH 23390 + cocaine groups. For the 0.5 $\mathrm{mg} / \mathrm{kg}$ dose of SCH 23390, this is due to enhanced activity in the saline group rather than a prevention of enhanced activity (sensitization) in the cocaine group. For the $0.1 \mathrm{mg} / \mathrm{kg} \mathrm{SCH} 23390$ groups, the results are intermediate between normal control values for saline-pretreated and cocaine-pretreated groups (no SCH 23390). However, after a 10-day withdrawal period, the response to cocaine in both the 0.1 and $0.5 \mathrm{mg} / \mathrm{kg} \mathrm{SCH}$ 23390 + saline groups had waned whereas that in $\mathrm{SCH}$ 23390 + cocaine groups had further increased indicating clear sensitization. These results suggest that behavioral supersensitivity in the $0.5 \mathrm{mg} / \mathrm{kg} \mathrm{SCH} 23390+$ saline group may result from functional supersensitivity of $D_{1}$ receptors within the nucleus accumbens. As for the $0.1 \mathrm{mg} / \mathrm{kg}$ SCH 23390 groups, it appears that the antagonist had in some way "masked" or delayed the induction of sensitization at the 3-day, but not the 10day, withdrawal time.

Because of the equivocal nature of the $0.1 \mathrm{mg} / \mathrm{kg}$ SCH 23390 results, we treated additional groups of rats with this dose and tested them at both the 3- and 10-day withdrawal periods. Again, both SCH 23390 + saline and SCH 23390 + cocaine groups exhibited intermediate ambulation scores as compared to the saline and cocaine control groups when tested after a 3-day withdrawal (Figure 5). But at the 10-day withdrawal time, clear sensitization was observed in both the saline $+\mathrm{co}^{-}$ caine and SCH 23390 + cocaine groups, and the ambulation scores for the SCH $23390+$ saline group had returned to levels comparable to the saline + saline group (Figure 5). So, SCH 23390 did not prevent cocaine sensitization, but appeared to mask it (or delay it) during the first test session. As with eticlopride, the lack of antagonism cannot be attributed to insufficient doses of $\mathrm{SCH}$ 23390, because even the lower doses prevented the acute locomotor effects of cocaine (Figure 6). In addition, the lowest dose $(0.5 \mathrm{mg} / \mathrm{kg})$ prevented the expression of sensitization when tested (as above) on day 12 (Figure 6 inset).

bar). Bottom panel: In separate groups of rats tested after 10 days of withdrawal, it is clear that SCH 23390 failed to prevent cocaine sensitization. A Kruskal-Wallis ANOVA (normality assumption failed) revealed a significant groups effect $\left(H_{7}=57.27, p<.001\right)$ and pairwise comparisons indicated that each cocaine group differed significantly from its respective control ( $\left.{ }^{*} p<0.05\right)$, that none of the control groups differed from one another, and that none of the cocaine groups differed from one another. 
Repeated Administration of SCH 23390, at $0.5 \mathrm{mg} / \mathrm{kg}$, Increased the Responsiveness of Nucleus Accumbens Neurons to a $D_{1}$ Receptor Agonist

To test whether the enhanced behavioral effects of cocaine in the SCH 23390 + saline groups resulted from $\mathrm{D}_{1}$ receptor supersensitivity induced by the repeated administration of SCH 23390, we conducted electrophysiological recordings of nucleus accumbens neurons. Rats received five daily injections of either the 0.1 or 0.5 $\mathrm{mg} / \mathrm{kg}$ doses of SCH 23390 and were prepared for recording after either a 3- or 10-day withdrawal period. Only the highest dose of SCH 23390 enhanced the abil-

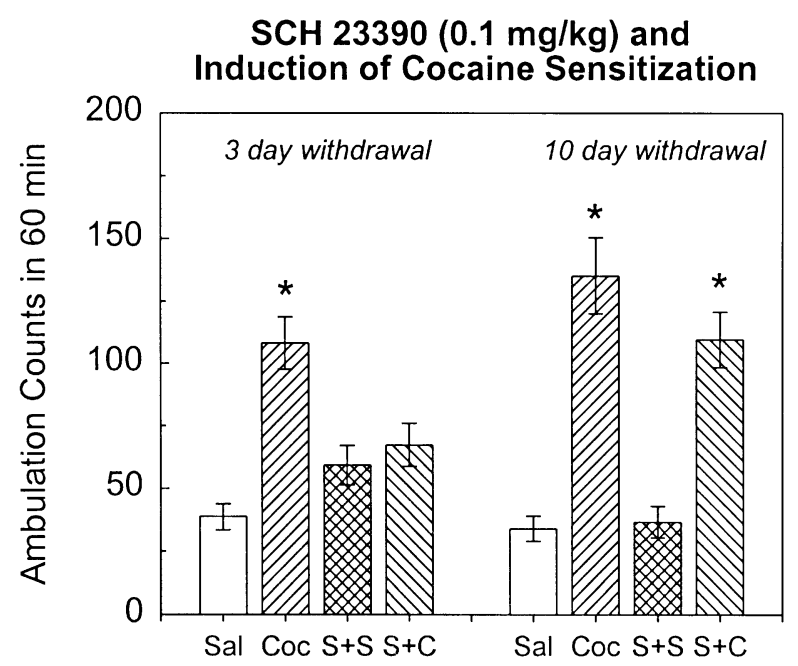

Figure 5. SCH $23390(0.1 \mathrm{mg} / \mathrm{kg})$ masked or delayed the appearance of cocaine sensitization but did not prevent it. In this experiment, the same groups of rats was tested with 7.5 $\mathrm{mg} / \mathrm{kg}$ cocaine at both the 3- and 10-day withdrawal times. The results obtained after 3 days of withdrawal suggest that SCH 23390 has prevented the induction of cocaine sensitization. ANOVA revealed a significant groups effect $\left(F_{3,47}=\right.$ $15.92, p<.001, n=12$ /group) and paired comparisons indicated that the cocaine $(\mathrm{Coc})$ group differed significantly from all other groups $\left({ }^{*} p<.05\right)$, and that the SCH $23390+$ saline $(S+S)$ and the SCH $23390+$ cocaine $(S+C)$ groups were not significantly different from the saline control group. However, after a 10-day withdrawal, a cocaine challenge to these same groups of rats clearly indicated that $\mathrm{SCH}$ 23390 had not prevented the induction of cocaine sensitization. A Kruskal-Wallis ANOVA on ranks (equal variance assumption failed) indicated a significant groups effect $\left(\mathrm{H}_{3}=\right.$ 34.92, $p<0.001$ ) and pairwise comparisons revealed that both the cocaine group and the SCH $23390+$ cocaine $(\mathrm{S}+\mathrm{C})$ group were significantly more active than either the saline or the SCH $23390+$ saline $(S+S)$ groups $\left({ }^{*} p<.05\right)$. As compared to the 3-day withdrawal results, the SCH $23390+$ saline group exhibited significantly less activity during the 10-day withdrawal challenge $\left(t_{11}=-3.11, p=.01\right.$, paired $t$-test), i.e., this group had returned to control levels, whereas the SCH $23390+$ cocaine group significantly increased its activity $\left(t_{11}=4.16, p=.002\right.$, paired $t$-test $)$. ity of the $D_{1}$ receptor agonist SKF 38393 to suppress glutamate-evoked activity of nucleus accumbens neurons. The apparent supersensitivity was highly significant at three days of withdrawal, but had waned considerably by 10 days (Figure 7). In contrast, the $0.1 \mathrm{mg} /$ $\mathrm{kg}$ dose of SCH 23390 slightly enhanced the responsiveness of nucleus accumbens neurons, but the effect was not statistically significant. The responses of nucleus accumbens neurons to quinpirole were unaltered by either SCH 23390 treatment (not shown). These findings suggest that the enhanced behavioral responses to cocaine in rats that received daily injections of $0.5 \mathrm{mg} / \mathrm{kg}$ SCH 23390 + saline resulted from the ability of the antagonist to induce functional $D_{1}$ receptor supersensitivity at the early withdrawal time.

\section{Administration of SCH 23390 During Withdrawal from Repeated Cocaine Also Failed to Prevent the Induction of Cocaine Sensitization}

The fact that cocaine sensitization appeared to be blunted by the intermediate dose of SCH 23390 at an early, but not late, withdrawal time, suggests that cellular adaptations responsible for sensitization might have been somehow delayed by $\mathrm{D}_{1}$ receptor antagonism. In addition,

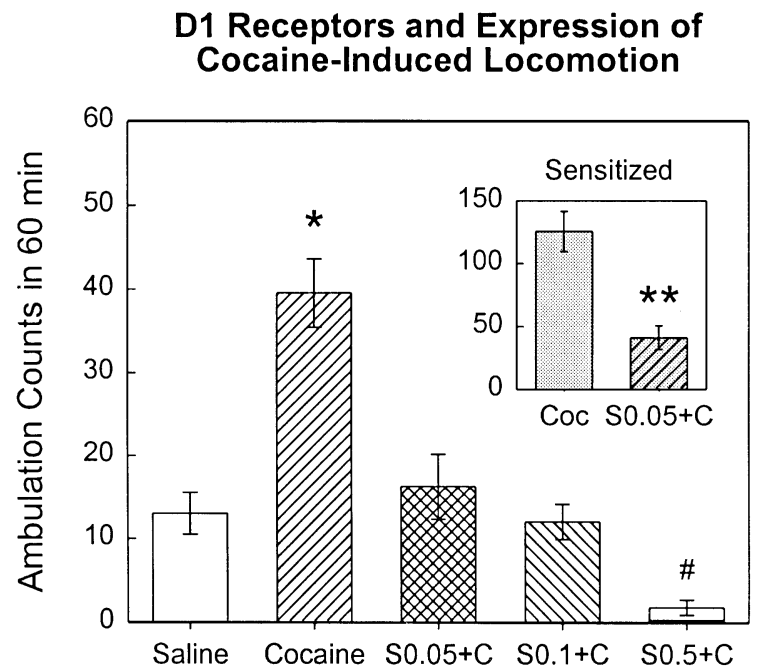

Figure 6. The $\mathrm{D}_{1}$ receptor-selective antagonist SCH 23390 prevented the acute locomotor stimulant effects of cocaine and the sensitized behavior observed after repeated cocaine administration. All three doses of SCH 23390 (S) prevented the acute locomotor activation produced by cocaine $(\mathrm{C})$. ANOVA revealed a significant groups effect $\left(F_{4,29}=17.35\right.$, $p<.001)$; pairwise comparisons indicated that the cocaine group was significantly higher than the saline group $\left({ }^{*} p<\right.$ $.05)$ and that the highest dose of SCH $23390(0.5 \mathrm{mg} / \mathrm{kg})$ reduced locomotion below the saline group $\left({ }^{*} p<.05, n=6\right.$ / group). Inset: The lowest dose of SCH $23390(0.05 \mathrm{mg} / \mathrm{kg})$ significantly ( $t_{10}=5.67, p<.001, n=6$ /group) prevented the sensitized locomotor response to cocaine $(C)$. 
the greater sensitization observed after the longer withdrawal suggests that additional adaptations are taking place during withdrawal that lead to a further enhancement of behavior. Might $D_{1}$ receptors be involved in

\section{Supersensitivity of NAc Neurons to D1 Receptor Stimulation}

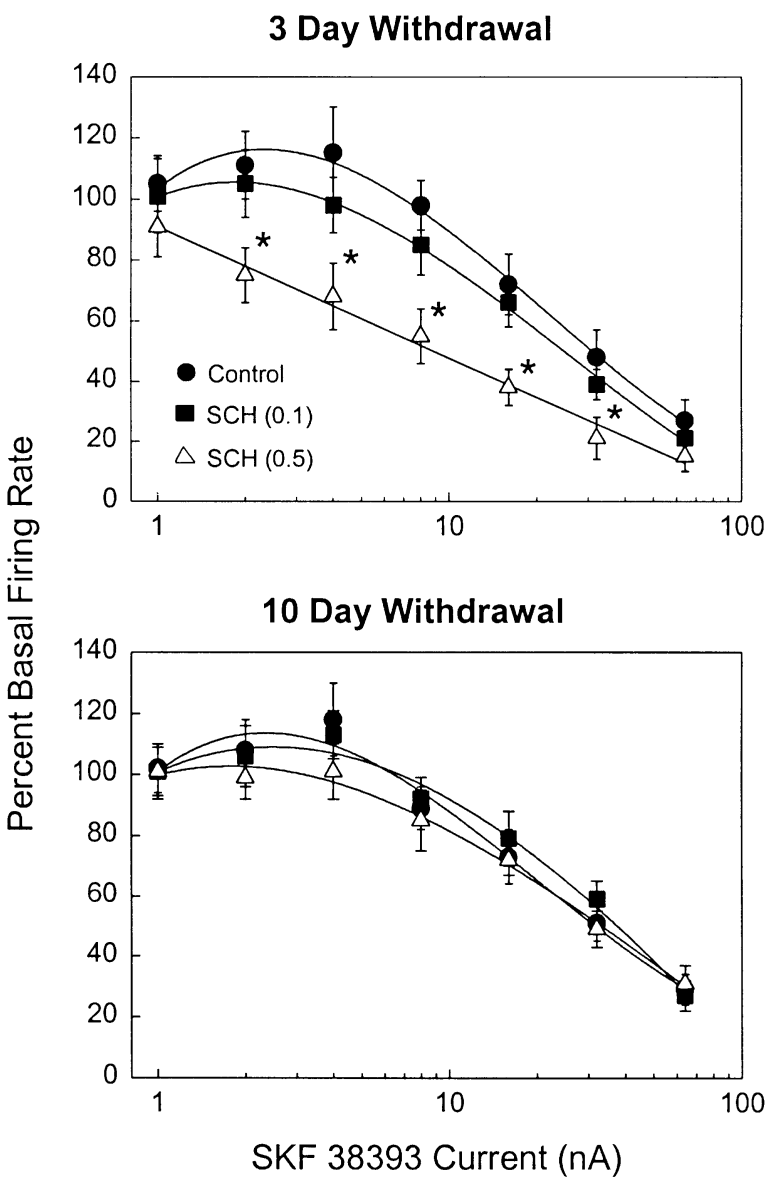

Figure 7. Repeated administration of a high dose of $\mathrm{SCH}$ 23390 (0.5 mg/kg for 5 days) produced functional $D_{1}$ receptor supersensitivity in the nucleus accumbens. Top panel: Percentage of basal (glutamate-driven) firing rate is plotted as a function of iontophoretic current $(n A)$ used to deliver the $D_{1}$ receptor-selective agonist SKF 38393. Repeated measures ANOVA indicated that sensitivity of nucleus accumbens neurons to SKF 38393 was significantly enhanced by repeated administration of SCH $23390(0.5 \mathrm{mg} / \mathrm{kg})$ when tested after 3 days of withdrawal $\left(F_{2,26}=14.95, p<.001\right.$; Dunnett's planned comparison with $\left.{ }^{*} p<.05\right)$. A trend towards supersensitivity was observed in the neurons recorded from rats that had received repeated administration of the antagonist at 0.01 $\mathrm{mg} / \mathrm{kg}$, but this effect was not statistically significant. Sample sizes are: $n=9$ neurons from four rats for control, $n=10$ neurons from five rats for both doses of SCH 23390. Bottom panel: No supersensitivity was evident after a 10-day withdrawal from repeated SCH 23390 treatment $\left(F_{2,26}=0.16, p=0.85\right)$. Sample sizes are: $n=$ nine neurons from five rats for control, $n=10$ neurons from five rats for both doses of SCH 23390. such processes? If so, then the presence of a $\mathrm{D}_{1}$ receptor antagonist during the withdrawal period might reduce cocaine sensitization. Therefore, we treated additional groups of rats with our standard cocaine sensitization regimen, but in half of the rats, we initiated daily injections of SCH $23390(0.1 \mathrm{mg} / \mathrm{kg})$ on the day after the last cocaine injection (day 1 of withdrawal) and continued them for three additional days. The control group received daily saline injections. After a 7-day washout, we challenged the two groups with cocaine $(7.5 \mathrm{mg} /$ $\mathrm{kg}$ ). The presence of SCH 23390 during withdrawal did not alter the induction of cocaine sensitization (Figure 8).

\section{Combinations of $D_{1}$ and $D_{2}$ Receptor Antagonists Failed to Prevent the Induction of Cocaine Sensitization}

Many of the behavioral effects mediated by DA receptors require co-activation of $\mathrm{D}_{1}$ and $\mathrm{D}_{2}$ receptors (for reviews, see Waddington and Daly 1993; White and $\mathrm{Hu}$ 1993). To determine whether the induction of cocaine sensitization also requires coordinated activity at these two classes of receptors, we tried to prevent cocaine sensitization with a combination of eticlopride and $\mathrm{SCH}$ 23390. The combination of $0.05 \mathrm{mg} / \mathrm{kg} \mathrm{SCH} 23390+0.1$ $\mathrm{mg} / \mathrm{kg}$ eticlopride failed to prevent the induction of

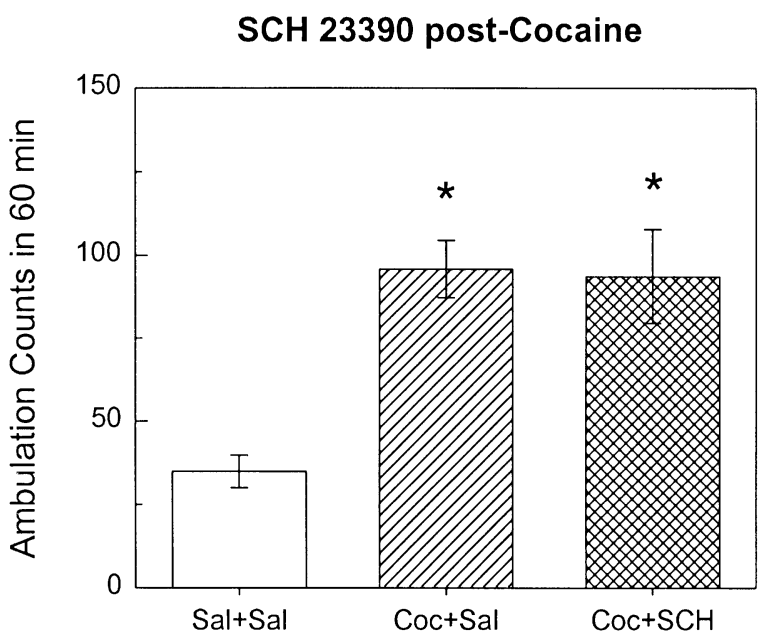

Figure 8. Daily injections of SCH 23390 during the first 4 days of cocaine withdrawal failed to prevent the induction of cocaine sensitization. Cocaine $(7.5 \mathrm{mg} / \mathrm{kg})$ produced significantly higher levels of activity in rats that received repeated cocaine administration, whether or not they received postcocaine treatment with SCH 23390 (0.1 mg/kg). KruskalWallis ANOVA on ranks (equal variance assumption failed) indicated a significant group effect $\left(H_{2}=19.17, p<0.001\right)$; Dunn's pairwise comparisons indicated that both the cocaine + saline (Coc+Sal) and the cocaine + SCH $23390(\mathrm{Coc}+\mathrm{SCH})$ groups differed from the saline + saline $\left(\right.$ sal + sal) group $\left({ }^{*} p<\right.$ $.05)$ and that the two cocaine groups did not differ from one another. 


\section{D1 + D2 Receptors and Induction of Cocaine Sensitization}

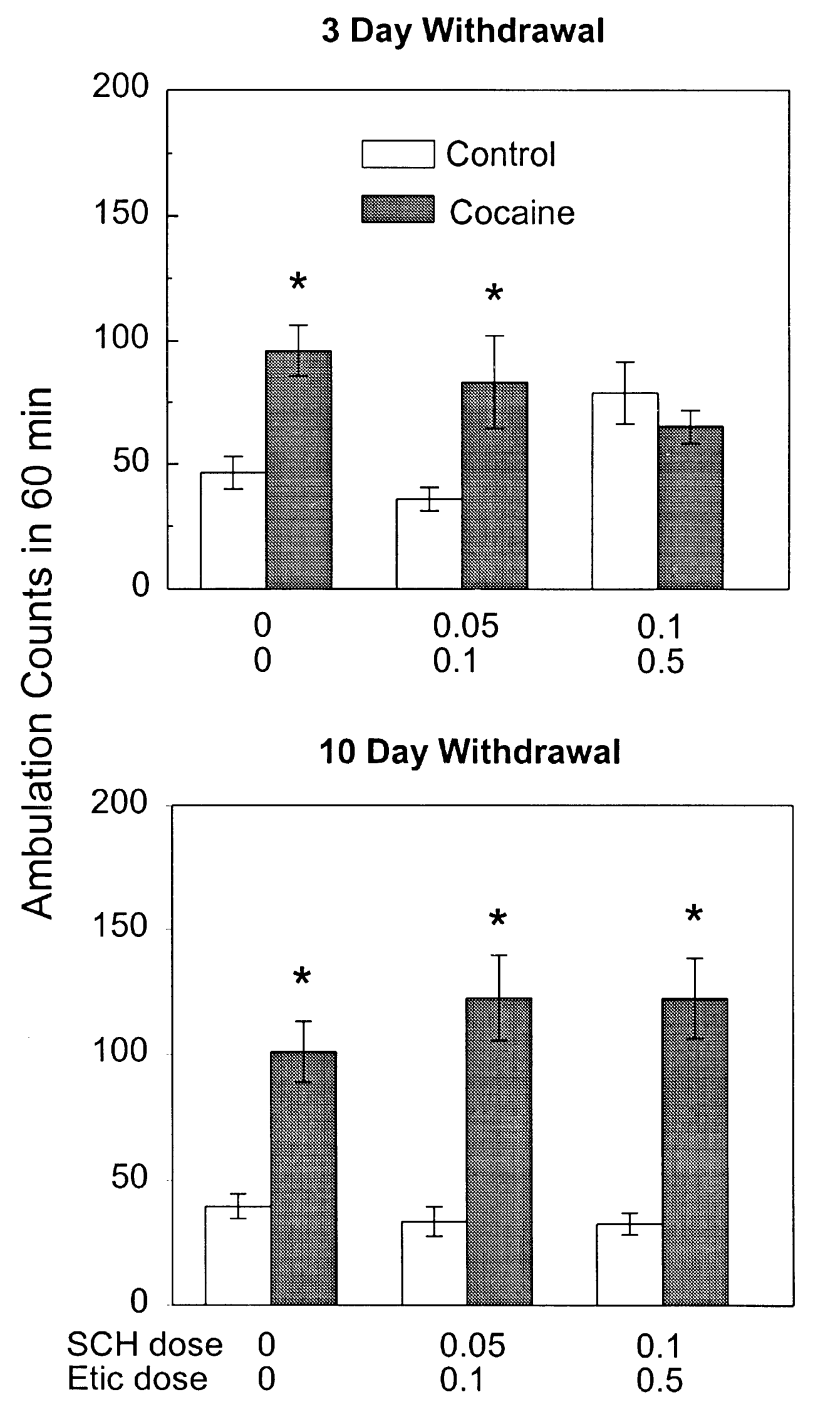

Figure 9. Antagonism of both $D_{1}$ and $D_{2}$ receptors failed to prevent induction of cocaine sensitization. Top panel: Coadministration of SCH 23390 and eticlopride with cocaine failed to prevent cocaine sensitization when tested with a 7.5 $\mathrm{mg} / \mathrm{kg}$ challenge after a 3-day withdrawal period. Note that when the higher doses of the two antagonists were used, there was apparent supersensitivity in the antagonists + saline group. ANOVA indicated a significant group effect $\left(F_{5,66}=5.24, p<.001, n=12\right.$ /group) and pairwise comparisons revealed that the cocaine groups in both the 0 antagonist and the lower dose antagonist combinations differed from their respective saline control groups $\left({ }^{*} p<.05\right)$. Bottom panel: After a 10-day withdrawal period, there is pronounced sensitization in all cocaine-treated rats indicating that the combination of the two antagonists was not able to prevent induction of cocaine sensitization. ANOVA indicated a significant group effect $\left(F_{5,66}=15.42, p<.001, n=12\right.$ /group) and paired comparisons indicated that each cocaine group differed from its respective control $\left({ }^{*} p<.05\right)$. sensitization (Figure 9), whereas the combination of the $0.1 \mathrm{mg} / \mathrm{kg} \mathrm{SCH} 23390+0.5 \mathrm{mg} / \mathrm{kg}$ eticlopride doses produced ambiguous results at the 3-day withdrawal, with the saline and cocaine groups exhibiting comparable ambulation counts that were intermediate between the saline and cocaine controls. As with the SCH 23390 alone results (above), a longer withdrawal period clarified this issue, because it is clear that cocaine sensitization was present at the 10-day withdrawal time (Figure 9).

\section{DISCUSSION}

Our findings indicate that antagonists of $\mathrm{D}_{1}$ and $\mathrm{D}_{2} \mathrm{DA}$ receptors, given either alone or in combination, do not prevent the induction of behavioral sensitization to cocaine. Similar findings have been presented by two other laboratories (Mattingly et al. 1994, 1996; Kuribara 1995b), although high doses of the $\mathrm{D}_{2}$ receptor antagonist haloperidol were effective in one report (Mattingly et al. 1996). We have extended the previous work in several ways including: (1) sensitization conditions in which context-dependency was minimized; (2) tests in which SCH 23390 was administered during the withdrawal period; (3) tests with another $\mathrm{D}_{2}$ receptor antagonist, eticlopride; (4) tests with combinations of the $\mathrm{D}_{1}$ and $\mathrm{D}_{2}$ antagonists; and most importantly (5) tests after longer periods of withdrawal. The latter results clarified what might have been interpreted as the prevention of sensitization when rats were tested at an earlier withdrawal period. We have also provided electrophysiological verification that certain doses of SCH 23390 induce behavioral supersensitivity to cocaine by enhancing $D_{1}$ receptor sensitivity within the nucleus accumbens. This and other aspects of the results make interpretation of such antagonist studies quite difficult, as discussed in detail below.

\section{$D_{2}$ Receptors Do Not Appear to Be Involved in the Induction of Cocaine Sensitization}

In our experiments, doses of eticlopride that were clearly sufficient to prevent the locomotor activating effects of acute cocaine failed to prevent the induction of sensitized locomotor activity. These findings are consistent with the majority of other work published on the topic. With repeated cocaine treatment regimens lasting for more than 1 day, the induction of sensitization was not prevented by the $D_{2}$ receptor-selective antagonists sulpiride in rats (Mattingly et al. 1994) or YM-09151-2 (cis-N-(-benzyl-2-methlpyrrolidin-3-yl)-5-chloro-2-nethoxy-4-methylaminobenzamide) in mice (Kuribara and Uchihashi 1993; Kuribara 1995b). The consistency of these findings contrasts with the variable results obtained with haloperidol, a $\mathrm{D}_{2}$ receptor-selective antagonist that also exhibits high affinities for other non-DA 
receptors. When tested during the induction phase of cocaine sensitization paradigms, haloperidol ( 0.1 and $0.05 \mathrm{mg} / \mathrm{kg}$, respectively) has been reported to both enhance (McCreary and Marsden 1993) and attenuate (Reimer and Martin-Iverson 1994) development of cocaine sensitization. However, induction and expression are confounded in these studies because the haloperidol + cocaine groups were never challenged with cocaine alone. A very high dose of haloperidol $(1.0 \mathrm{mg} / \mathrm{kg})$ appeared to prevent induction of cocaine sensitization (Mattingly et al. 1996), but this result was confounded by what appeared to be supersensitivity to cocaine in the haloperidol + vehicle control group (Mattingly et al. 1996). In addition, this dose of haloperidol binds to receptors other than $D_{2}$. In particular, such doses bind to $\sigma$ sites, and selective ligands for these sites have also been shown to prevent induction of cocaine sensitization (Ujike et al. 1996). Taken together, these results indicate that $D_{2}$ receptor-selective doses of haloperidol have yet to be tested with respect to induction of cocaine sensitization using typical repeated cocaine injection and test paradigms (locomotor activity).

If we put aside the haloperidol results, then the results with $\mathrm{D}_{2}$ receptor-selective antagonists are most simply interpreted as indicating that the $\mathrm{D}_{2}$ receptors are not involved in the induction of cocaine sensitization. The failure of $\mathrm{D}_{2}$ receptor antagonists to prevent cocaine sensitization cannot be attributed to different affinities for the various $\mathrm{D}_{2}$-like receptors $\left(\mathrm{D}_{2}, \mathrm{D}_{3}\right.$, and $\mathrm{D}_{4}$ ) because all of the antagonists (especially YM-09151-2), exhibit high affinities for all three of the receptors (Van Tol et al. 1991). So, are $D_{2}$ receptors not involved in the processes responsible for the induction and expression of cocaine sensitization, or are there other explanations for the antagonist results?

One possible explanation for the failure of $\mathrm{D}_{2}$ receptor antagonists to prevent the induction of cocaine sensitization is that the processes responsible for the induction are actually mimicked by $\mathrm{D}_{2}$ receptor blockade. For many years, we have argued that a fundamental process involved in the induction of psychomotor stimulant sensitization is an increase in the basal activity of VTA DA neurons (for reviews, see White and Wolf 1991; White et al. 1995a; White 1996). This can be accomplished by DA autoreceptor subsensitivity (Henry et al. 1989), enhanced sensitivity of glutamate receptors (White et al. 1995b), or other means. Antagonism of $\mathrm{D}_{2}$ receptors also enhances the firing rates of DA neurons (for review, see White 1996). Thus, whereas $\mathrm{D}_{2}$ receptor antagonism might prevent enhanced receptor stimulation by DA after cocaine administration, and thereby prevent the induction of autoreceptor subsensitivity, the functional consequences to the DA neurons are the same, i.e., repeated enhancements of neuronal discharge. This effect could trigger subsequent changes such as enhanced DA "releasibility" (e.g., see Kalivas and Duffy
1993; Heidbreder et al. 1996) which-combined with additional neuroadaptations, such as functional $D_{1}$ receptor supersensitivity (Henry and White 1991, 1995) ultimately produce a sensitized neuronal system. From this perspective, using $\mathrm{D}_{2}$ receptor antagonists would be an unsatisfactory experimental strategy to test possible roles of $D_{2}$ receptors in the induction of cocaine sensitization, because they mimic processes known to be involved in the induction of cocaine sensitization.

\section{$D_{1}$ Receptors Do Not Appear to Be Involved in the Induction of Cocaine Sensitization}

Our results indicate that doses of the $\mathrm{D}_{1}$ receptor antagonist SCH 23390, which completely prevent the locomotor-activating effects of cocaine (see also Ushijima et al. 1995; Tella 1996) do not prevent the induction of behavioral sensitization to cocaine. However, the results were not as clear as those obtained with the $\mathrm{D}_{2}$ receptor antagonist. Indeed, had we not conducted dose-response studies, included SCH 23390 + saline control groups, and examined both short and long duration withdrawal periods, we might have concluded that $\mathrm{SCH} 23390$, at a dose of $0.1 \mathrm{mg} / \mathrm{kg}$, prevented the induction of cocaine sensitization. At this dose, cocaine challenges after a 3-day withdrawal produced levels of locomotor activity that were intermediate between those observed in cocaine-naïve rats and cocaine-sensitized rats, but which were nearly identical to those in the corresponding $\mathrm{SCH}$ $23390+$ saline group. Only with the additional tests after the 10-day withdrawal were the results clear- $\mathrm{SCH}$ 23390 had not prevented cocaine sensitization but had, in some manner, masked the appearance of the enhanced behavior. This occurred whether we tested the same group of rats or separate groups of rats at the two withdrawal times. So, the results cannot be attributed to an influence of cocaine during the first test altering the response during the second test.

Our SCH 23390 results are similar to those previously reported by Mattingly and colleagues who failed to prevent the induction of sensitization with either 0.3 or $0.5 \mathrm{mg} / \mathrm{kg}$ doses (Mattingly et al. 1994, 1996). As in our study, the $0.5 \mathrm{mg} / \mathrm{kg}$ dose of SCH 23390 clearly enhanced the sensitivity of the rats in the SCH 23390 + vehicle control group to cocaine challenge. Kuribara also found that SCH $23390(0.01-0.1 \mathrm{mg} / \mathrm{kg})$ failed to prevent the induction of cocaine sensitization and, in fact, enhanced sensitivity to cocaine in mice (Kuribara and Uchihashi 1993; Kuribara 1995b). Our electrophysiological results indicating clear supersensitivity of nucleus accumbens neurons to the $D_{1}$ receptor-selective agonist SKF 38393 after the 3-day withdrawal confirm the speculations of these other authors that $\mathrm{D}_{1}$ receptor supersensitivity confounded the results with higher doses of SCH 23390 (Mattingly et al. 1994, 1996; Kuribara 1995b). 
How might certain doses of SCH 23390 "mask" cocaine sensitization during early withdrawal tests? It seems unlikely that there would be sufficient residual SCH 23390 in the brain three days after the last injection. Indeed, were that the case, one would expect greater masking at the $0.5 \mathrm{mg} / \mathrm{kg}$ dose, which instead produced clear supersensitivity. An alternative explanation is that although the $0.1 \mathrm{mg} / \mathrm{kg}$ dose of $\mathrm{SCH}$ 23390 is insufficient to produce clear $D_{1}$ receptor supersensitivity, as evidenced by our electrophysiological results, sensitivity is enhanced just enough to increase the behavioral effects of cocaine. This would imply that the enhanced behavior in the SCH 23390 + cocaine group was not due to sensitization but, like that of the $\mathrm{SCH}$ $23390+$ saline group, was a reflection of slight antagonist-induced supersensitivity. A similar but more robust antagonist-induced supersensitivity would also explain the enhanced behavioral responses to cocaine observed at the higher dose of SCH 23390.

Herein lies the problem with using $\mathrm{D}_{1}$ receptor antagonists to prevent cocaine sensitization. The effects of repeated $D_{1}$ receptor antagonist administration on nucleus accumbens neurons are the same as those of repeated cocaine administration, enhanced responsiveness of $\mathrm{D}_{1}$ receptors. We are not implying that the cellular mechanisms underlying the two forms of supersensitivity are identical. Indeed, $\mathrm{D}_{1}$ receptor antagonist-induced supersensitivity is associated with an increase in $\mathrm{D}_{1}$ receptor density (e.g., see Creese and Chen 1985; McGonigle et al. 1989) and is a relatively transient phenomenon. In contrast, the apparent $\mathrm{D}_{1}$ receptor supersensitivity produced by repeated cocaine administration occurs in the absence of such an increase, perhaps as a result of alterations in the cAMP-protein kinase A signaling system (for reviews, see Self and Nestler 1995; White et al. 1995a), and persists for at least a month after treatment cessation (Henry and White 1991, 1995). In fact, our recent findings indicate that $D_{1}$ receptors are not truly supersensitive during early withdrawal from repeated cocaine administration but appear to be so because nucleus accumbens neurons are less excitable as a result of a reduction in whole-cell sodium conductance (White et al. 1998). Nevertheless, the functional consequences of repeated SCH 23390 and repeated cocaine administration are similar-enhanced efficacy of DA's effects on $\mathrm{D}_{1}$ receptors.

The fact that cocaine sensitization was fully evident in all of the SCH 23390 + cocaine groups when they were tested after 10 days of withdrawal clearly demonstrates that blocking $D_{1}$ receptors before each cocaine injection does not prevent the induction of cocaine sensitization. Is it possible that the higher doses of $\mathrm{SCH}$ 23390 had somehow delayed the induction of cocaine sensitization? If so, then it follows that the critical events leading to the sensitized state can occur during the cocaine withdrawal period. This is certainly the case with enhanced releasibility of DA, an event which is not typically observed until later periods of withdrawal (Kalivas and Duffy 1993; Heidbreder et al. 1996). During the first 4 days of cocaine withdrawal, an increase in DA neuronal activity within the VTA (Henry et al. 1989) leads to enhanced basal synaptic DA concentrations in the nucleus accumbens (Weiss et al. 1992; Heidbreder et al. 1996). We reasoned that enhanced $D_{1}$ receptor stimulation by endogenous DA during this period might induce neuroadaptations necessary for cocaine sensitization. However, we found that blocking $\mathrm{D}_{1}$ receptors during the first 4 days of withdrawal was also unable to prevent the induction of sensitization when tested on the tenth day of withdrawal.

Taken together, the results of experiments with $\mathrm{SCH}$ 23390 indicate that $D_{1}$ receptor stimulation is not required for the induction of cocaine sensitization. It might be argued that $D_{1}$ receptors are involved in the events responsible for inducing sensitization, but that there are redundant pathways engaged by cocaine that can still lead to the necessary neuroadaptations. Thus, when one pathway is not available, the other can still evoke the relevant mechanisms. Indeed, cocaine causes substantial increases in extracellular serotonin in the nucleus accumbens, an effect that is altered by repeated cocaine administration and withdrawal (Parsons et al. 1995). Since, under certain conditions, many nucleus accumbens neurons are inhibited by either DA or serotonin (White et al. 1993), it is conceivable that redundant DA and serotonin mechanisms exist for the induction of sensitization-relevant neuroadaptations. Nevertheless, $D_{1}$ receptors clearly do not play the sort of essential role in the induction of cocaine sensitization that is played by other receptor systems, most notably the ionotropic glutamate receptors (Karler et al. 1989, 1994). Indeed, direct tests have demonstrated that antagonists of NMDA receptors truly prevent rather than mask the induction of cocaine sensitization (Wolf and Jeziorski 1993).

\section{Antagonism of Both $D_{1}$ and $D_{2}$ Receptors Failed to Prevent Induction of Cocaine Sensitization}

A reasonable explanation for the inability of selective $D_{1}$ and $D_{2}$ receptor antagonists to prevent cocaine sensitization is that both receptor populations are involved in the processes underlying this form of plasticity. It is well established that most of the unconditioned behavioral effects produced by enhanced DA transmission require both $D_{1}$ and $D_{2}$ receptor stimulation and that similar relationships exist with respect to the electrophysiological effects of DA within the striatum (for reviews, see Waddington and Daly 1993; White and $\mathrm{Hu}$ 1993). However, even with combinations of eticlopride and SCH 23390, we were unable to prevent the induction of cocaine sensitization. As in the SCH 23390 exper- 
iments, the use of the $0.1 \mathrm{mg} / \mathrm{kg}$ dose, in combination with eticlopride, appeared to prevent the induction of sensitization at the early withdrawal time. However, this was again due to some masking of the underlying processes, because sensitization was clearly evident when tested after 10 days of withdrawal. Thus, the failure of either $D_{1}$ or $D_{2}$ receptor antagonists, administered alone, to prevent induction of cocaine sensitization was not due to dopamine acting at the other class of receptors.

\section{$D_{1}$, but Not $D_{2}$, Receptor Antagonists Prevent Expression of Cocaine Sensitization}

Once behavioral sensitization was induced by repeated cocaine administration, SCH 23390, but not eticlopride, prevented the expression of the enhanced locomotor activity. Many previous studies have found that the $D_{1}$ receptor-selective antagonist prevents expression of cocaine sensitization during the development phase (Kuribara and Uchihashi 1993; McCreary and Marsden 1993; Mattingly et al. 1994, 1996; Tella 1994; Kuribara 1995b). Our results extend the basic finding to tests conducted after sensitization was fully induced. This is important because haloperidol has been reported to prevent expression of cocaine sensitization during the treatment regimen, when high doses $(1.0 \mathrm{mg} / \mathrm{kg})$ or IV injections (0.03-0.3 mg/kg) are used (Tella 1994; Mattingly et al. 1996), but not when low doses $(0.05 \mathrm{mg} / \mathrm{kg})$ are tested after induction of sensitization (Martin-Iverson and Reimer 1994). In addition, other $D_{2}$ receptor-selective antagonists appear to dampen the expression of cocaine sensitization during the development phase (Kuribara and Uchihashi 1993; Mattingly et al. 1994; Kuribara 1995b), but our findings with relatively high doses of eticlopride confirm that selective antagonism of $\mathrm{D}_{2}$ receptors does not prevent the expression of cocaine sensitization once it has been established. Taken together, these findings are consistent with our earlier electrophysiological reports indicating that the expression of behavioral sensitization to cocaine is temporally correlated with the state of $D_{1}$, but not $D_{2}$, receptor sensitivity in the nucleus accumbens (Henry and White 1991, 1995).

\section{DA Receptors and Conditioning Processes Involved in Cocaine Sensitization}

In contrast to the results indicating that DA receptors are not involved in the induction of cocaine sensitization when repeated injection protocols are used during the development phase, other procedures designed to test for conditioning processes involved in cocaine sensitization have suggested a role for DA receptors. In the one-shot, context-dependent paradigm designed by Post and colleagues, both $\mathrm{D}_{1}$ and $\mathrm{D}_{2}$ receptor antagonists prevent the induction of enhanced sensitivity to cocaine (Weiss et al. 1989; Fontana et al. 1993). SCH
23390 also prevents the acquisition of cocaine-induced conditioned locomotion, tested with vehicle injections after repeated cocaine administration (Cervo and Samanin 1996), as well as sensitization to the conditioned rewarding effects of cocaine in the place preference procedure (Shippenberg and Heidbreder 1995). As for $D_{2}$ receptor-selective antagonists, they fail to prevent either cocaine-induced conditioned activity (Reimer and Martin-Iverson 1994; Cervo and Samanin 1996) or the conditioned rewarding effects of cocaine (Shippenberg and Heidbreder 1995). These findings indicate that $D_{1}$ receptors are primarily involved in conditioning processes that impact upon cocaine sensitization, and that the one-shot cocaine treatment paradigm must involve processes that differ from those involved in both cocaine-induced conditioned locomotion and more typical multiple injection cocaine sensitization paradigms.

If $\mathrm{D}_{1}$ receptors are involved in conditioning processes during cocaine sensitization, but not in the pharmacological mechanisms responsible for the induction of cocaine sensitization, then it follows that conditioning plays little role in our sensitization paradigm. We give the daily injections of cocaine in the animals' home cages, but we then test in a different environment. Our test chambers are not totally novel because we use the same type of housing cages for our test chamber. However, many other aspects of the test environment differ (e.g., different room, lack of other animals in the cage, etc., see methods for details), such that context-dependency is minimized. Recent evidence suggests that both cocaine sensitization and conditioned locomotion are enhanced by administering repeated cocaine injections in a novel environment (Badiani et al. 1995). Accordingly, one might expect that $D_{1}$ receptor antagonists would be more effective in preventing induction of sensitization in paradigms that use novel environments during the treatment protocol. However, this was not the case in earlier studies (Kuribara and Uchihashi 1993; Mattingly et al. 1994, 1996; Kuribara 1995b). So, it may be that during repeated cocaine injections, the pharmacological mechanisms responsible for cocaine sensitization are sufficient to overcome any lack of conditioning as a result of $D_{1}$ receptor blockade.

\section{Why Do DA Receptor Antagonists Prevent Induction of Amphetamine, but Not Cocaine, Sensitization?}

What is most surprising about the inability of DA receptor antagonists to prevent induction of cocaine sensitization is the relatively consistent findings of several investigators that these drugs do prevent amphetamine sensitization. Indeed, every study to date indicates that SCH 23390 prevents induction of amphetamine sensitization, and in most studies (for exceptions, see Vezina and Stewart 1989; Vezina 1996), $\mathrm{D}_{2}$ receptor blockers have also been found effective (Kuczenski and Leith 
1981; Ujike et al. 1989; Hamamura et al. 1991; Kuribara and Uchihashi 1993, 1994; Kuribara 1995a,c). As discussed by Vezina (1996), the $\mathrm{D}_{2}$ receptor antagonism studies in amphetamine sensitization are complicated by issues of selectivity (e.g., haloperidol), as well as potential differences between amphetamine and methamphetamine. However, the results with SCH 23390 are remarkably consistent. Such results cannot be attributed to masking of relevant neuroadaptations because sensitization was not evident even 3 months after cessation of treatment (Hamamura et al. 1991). We also have preliminary evidence that sensitization to amphetamine-induced ambulation is prevented by SCH 23390 $(0.01 \mathrm{mg} / \mathrm{kg})$ using our treatment and test conditions (Koeltzow et al. 1997). What is different about cocaine sensitization that renders it insensitive to DA receptor antagonists? One possible difference is that, unlike amphetamine sensitization (for review, see Robinson and Becker 1986), cocaine sensitization involves pharmacokinetic alterations leading to enhanced brain concentrations of the drug after repeated administration (Reith et al. 1987; Pettit et al. 1990; Cass and Zahniser 1993). DA receptor antagonists would not be expected to prevent such dispositional alterations. However, it is generally accepted that the increase in brain cocaine levels produced by repeated administration is insufficient to account for behavioral sensitization (Reith et al. 1987; Cass and Zahniser 1993). In addition, pharmacokinetic alterations cannot explain the numerous neuroadaptations that occur during repeated cocaine administration. Another compelling speculation is that, as compared to amphetamine, cocaine exerts considerably greater effects on serotonin neurons. Indeed, microdialysis studies have indicated that cocaine causes nearly a $300 \%$ increase in striatal levels of both DA and serotonin (Bradberry 1994; Essman et al. 1994), whereas amphetamine produces profound $(500 \%)$ increases in DA but, even at relatively high doses, only a short-lived $100 \%$ increase in serotonin (Kuczenski and Segal 1989). As mentioned above, there may be convergent regulation of nucleus accumbens neurons by DA and serotonin such that when DA receptors are blocked, serotonin can still produce the necessary neuroadaptations leading to sensitization.

\section{CONCLUSIONS}

Our findings clearly indicate that the induction of cocaine sensitization is not prevented by DA receptor antagonists, but that the expression of the enhanced behavior requires $D_{1}$ receptor stimulation. The apparent blockade observed at short withdrawal times with certain doses of the $\mathrm{D}_{1}$ receptor antagonist SCH 23390 resulted from a masking of sensitization because after a longer withdrawal period, sensitization was robust.
Our results emphasize the necessity of testing for behavioral sensitization at more than withdrawal time, of testing more than one dose of an antagonist, and of including antagonist + vehicle control groups. Without these components of our experiments, we could easily have reached false conclusions regarding the role of $D_{1}$ receptors in the induction of cocaine sensitization. The fact that DA receptor antagonists prevent context-dependent, one-shot cocaine sensitization indicates that this form of behavioral supersensitivity involves different mechanisms than more traditional multiple dose sensitization regimens. More importantly, the fact that DA receptor antagonists prevent amphetamine, but not cocaine, sensitization cautions against overgeneralizing with respect to mechanisms of psychomotor stimulantinduced sensitization. Although cross-sensitization between various psychomotor stimulants has been used as an argument for similar mechanisms involved in sensitization processes, it appears that different events may occur during the induction of sensitization with various drugs that then lead to similar neuroadaptations involved in the expression of enhanced behavioral responsiveness.

\section{ACKNOWLEDGMENTS}

We thank Pamela Alvarez and Lorinda Baker for technical assistance, and Dr. M.E. Wolf for helpful comments and suggestions. This work was supported by USPHS Grant DA04093 from the National Institute on Drug Abuse (NIDA). FJW is also the recipient of a NIDA Research Scientist Development Award (DA00207).

\section{REFERENCES}

Badiani A, Browman KE, Robinson TE (1995): Influence of novel versus home environments on sensitization to the psychomotor stimulant effects of cocaine and amphetamine. Brain Res 674:291-298

Beninger RJ, Herz RS (1986): Pimozide blocks establishment but not expression of cocaine-induced environmentspecific conditioning. Life Sci 38:1425-1431

Bjijou Y, Stinus L, Le Moal M, Cador M (1996): Evidence for selective involvement of dopamine $D_{1}$ receptors of the ventral tegmental area in the behavioral sensitization induced by intra-ventral tegmental area injections of D-amphetamine. J Pharmacol Exp Ther 277:1177-1187

Bradberry CW (1994): Microdialysis assessment of the impact of (+)3,4-methylenedioxymethamphetamine, cocaine, and cocaethylene on serotonergic neurons. Drug Dev Res 33:1-9

Cass WA, Zahniser NR (1993): Cocaine levels in striatum and nucleus accumbens: Augmentation following challenge injection in rats withdrawn from repeated cocaine administration. Neurosci Lett 152:177-180

Cervo L, Samanin R (1996): Effects of dopaminergic and 
glutamatergic receptor antagonists on the establishment and expression of conditioned locomotion to cocaine in rats. Brain Res 731:31-38

Creese I, Chen A (1985): Selective D-1 dopamine receptor increase following chronic treatment with SCH 23390. Eur J Pharmacol 109:127-128

Essman WD, Singh A, Lucki I (1994): Serotonergic properties of cocaine: Effects on a $5-\mathrm{HT}_{2}$ receptor-mediated behavior and on extracellular concentrations of serotonin and dopamine. Pharmacol Biochem Behav 49:107-113

Fontana D, Post RM, Weiss SRB, Pert A (1993): The role of $\mathrm{D}_{1}$ - and $\mathrm{D}_{2}$-dopamine receptors in the acquisition and expression of cocaine-induced conditioned increases in locomotor behavior. Behav Pharmacol 4:375-387

Hamamura T, Akiyama K, Akimoto K, Kashihara K, Okumura K, Ujike H, Otsuki S (1991): Co-administration of either a selective $D_{1}$ or $D_{2}$ dopamine antagonist with amphetamine prevents methamphetamine-induced behavioral sensitization and neurochemical change, studied by in vivo intracerebral dialysis. Brain Res 546:40-46

Heidbreder CA, Thompson AC, Shippenberg TS (1996): Role of extracellular dopamine in the initiation and longterm expression of behavioral sensitization to cocaine. J Pharmacol Exp Ther 278:490-502

Henry DJ, Greene MA, White FJ (1989): Electrophysiological effects of cocaine in the mesoaccumbens dopamine system: repeated administration. J Pharmacol Exp Ther 251:833-839

Henry DJ, White FJ (1991): Repeated cocaine administration causes persistent enhancement of $D_{1}$ dopamine receptor sensitivity within the rat nucleus accumbens. J Pharmacol Exp Ther 258:882-890

Henry DJ, White FJ (1995): The persistence of behavioral sensitization to cocaine parallels enhanced inhibition of nucleus accumbens neurons. J Neurosci 15:6287-6299

$\mathrm{Hu}$ X-T, White FJ (1994): Loss of $\mathrm{D}_{1} / \mathrm{D}_{2}$ dopamine receptor synergisms following repeated administration of $D_{1}$ or $\mathrm{D}_{2}$ receptor selective antagonists: Electrophysiological and behavioral studies. Synapse 17:43-61

Kalivas PW (1995): Neural basis of behavioral sensitization to cocaine. In Hammer RP, Jr (ed), The Neurobiology of Cocaine: Cellular and Molecular Mechanisms. Boca Raton, FL, CRC Press, pp 81-98

Kalivas PW, Duffy P (1993): Time course of extracellular dopamine and behavioral sensitization to cocaine. I. Dopamine axon terminals. J Neurosci 13:266-275

Kalivas PW, Stewart J (1991): Dopamine transmission in the initiation and expression of drug- and stress-induced sensitization of motor activity. Brain Res Rev 16:223-224

Karler R, Calder LD, Chaudhry IA, Turkanis SA (1989): Blockade of "reverse tolerance" to cocaine and amphetamine by MK-801. Life Sci 45:599-606

Karler R, Calder LD, Bedingfield JB (1994): Cocaine behavioral sensitization and the excitatory amino acids. Psychopharmacology (Berl) 115:305-310

Koeltzow TE, Joshi A, Hu X-T, Wolf ME, White FJ (1997): Dopamine receptor antagonists and the induction of sensitization to cocaine and amphetamine. Soc Neurosci Abst 23 (in press)

Koob GF (1992): Drugs of abuse: anatomy, pharmacology and function of reward pathways. Trends Pharmacol Sci 13:177-184

Kuczenski R, Leith NJ (1981): Chronic amphetamine: Is dopamine a link in or a mediator of the development of tolerance and reverse tolerance? Pharmacol Biochem Behav 15:405-413

Kuczenski R, Segal DS (1989): Concomitant characterization of behavioral and striatal neurotransmitter response to amphetamine using in vivo microdialysis. J Neurosci 9:2051-2065

Kuribara H (1995a): Dopamine $\mathrm{D}_{1}$ receptor antagonist $\mathrm{SCH}$ 23390 retards methamphetamine sensitization in both combined administration and early posttreatment schedules in mice. Pharmacol Biochem Behav 52:759-763

Kuribara H (1995b): Modification of cocaine sensitization by dopamine $D_{1}$ and $D_{2}$ receptor antagonists in terms of ambulation in mice. Pharmacol Biochem Behav 51:799-805

Kuribara H (1995c): Inhibition of methamphetamine sensitization by post-methamphetamine treatment with SCH 23390 or haloperidol. Psychopharmacology (Berl) 119:34-38

Kuribara H, Uchihashi Y (1993): Dopamine antagonists can inhibit methamphetamine sensitization, but not cocaine sensitization, when assessed by ambulatory activity in mice. J Pharm Pharmacol 45:1042-1045

Kuribara H, Uchihashi Y (1994): Effects of dopamine antagonism on methamphetamine sensitization: Evaluation by ambulatory activity in mice. Pharmacol Biochem Behav 47:101-106

Martin-Iverson MT, Reimer AR (1994): Effects of nimodipine and/or haloperidol on the expression of conditioned locomotion and sensitization to cocaine in rats. Psychopharmacology (Berl) 114:315-320

Mattingly BA, Hart TC, Lim K, Perkins C (1994): Selective antagonism of dopamine $D_{1}$ and $D_{2}$ receptors does not block the development of behavioral sensitization to cocaine. Psychopharmacology (Berl) 114:239-242

Mattingly BA, Rowlett JK, Ellison T, Rase K (1996): Cocaineinduced behavioral sensitization: Effects of haloperidol and SCH 23390 treatments. Pharmacol Biochem Behav 53:481-486

McCreary AC, Marsden CA (1993): Cocaine-induced behaviour: Dopamine $D_{1}$ receptor antagonism by SCH 23390 prevents expression of conditioned sensitisation following repeated administration of cocaine. Neuropharmacology 32:387-391

McGonigle P, Boyson SJ, Reuter S, Molinoff PB (1989): Effects of chronic treatment with selective and nonselective antagonists on the subtypes of dopamine receptors. Synapse 3:74-82

Parsons LH, Koob GF, Weiss F (1995): Serotonin dysfunction in the nucleus accumbens of rats during withdrawal after unlimited access to intravenous cocaine. J Pharmacol Exp Ther 274:1182-1191

Pettit HO, Pan H-T, Parsons LH, Justice JB, Jr. (1990): Extracellular concentrations of cocaine and dopamine are enhanced during chronic cocaine administration. J Neurochem 55:798-804

Post RM (1980): Intermittent versus continuous stimulation: Effect of time interval on the development of sensitization or tolerance. Life Sci 26:1275-1282 
Post RM, Weiss SRB, Pert A (1992): Sensitization and kindling effects of chronic cocaine administration. In Lakoski JM, Galloway MP, White FJ (eds), Cocaine: Pharmacology, Physiology and Clinical Strategies. Boca Raton, FL, CRC Press, pp 115-161

Post RM, Contel NR (1983): Human and animal studies of cocaine: Implications for development of behavioral pathology. In Creese I (ed), Stimulants: Neurochemical, Behavioral and Clinical Perspectives. New York, Raven Press, pp 169-203

Reimer AR, Martin-Iverson MT (1994): Nimodipine and haloperidol attenuate behavioral sensitization to cocaine but only nimodipine blocks the establishment of conditioned locomotion by cocaine. Psychopharmacology 113:404-410

Reith MEA, Benuck M, Lajtha A (1987): Cocaine disposition in the brain after continuous or intermittent treatment and locomotor stimulation in mice. J Pharmacol Exp Ther 243:281-287

Ritz MC, Lamb RJ, Goldberg SR, Kuhar MJ (1987): Cocaine receptors on dopamine transporters are related to selfadministration of cocaine. Science 237:1219-1223

Robinson TE, Becker JB (1986): Enduring changes in brain and behavior produced by chronic amphetamine administration: A review and evaluation of animal models of amphetamine psychosis. Brain Res Rev 11:157-198

Robinson TE, Berridge KC (1993): The neural basis of drug craving: An incentive-sensitization theory of addiction. Brain Res Rev 18:247-291

Self DW, Nestler EJ (1995): Molecular mechanisms of drug reinforcement and addiction. Annu Rev Neurosci 18:463495

Shippenberg TS, Heidbreder C (1995): Sensitization to the conditioned rewarding effects of cocaine: Pharmacological and temporal characteristics. J Pharmacol Exp Ther 273:808-815

Stewart J, Badiani A (1993): Tolerance and sensitization to the behavioral effects of drugs. Behav Pharmacol 4:289-312

Stewart J, Vezina P (1989): Microinjections of SCH 23390 into the ventral tegmental area and substantia nigra pars reticulata attenuate the development of sensitization to the locomotor activating effects of systemic amphetamine. Brain Res 495:401-406

Tella SR (1994): Differential blockade of chronic versus acute effects of intravenous cocaine by dopamine receptor antagonists. Pharmacol Biochem Behav 48:151-159

Tella SR (1996): Possible novel pharmacodynamic action of cocaine: Cardiovascular and behavioral evidence. Pharmacol Biochem Behav 54:343-354

Ujike $\mathrm{H}$, Onoue T, Akiyama K, Hamamura T, Otsuki S (1989): Effects of selective D-1 and D-2 dopamine antagonists on development of methamphetamine-induced behavioral sensitization. Psychopharmacology 98:89-92

Ujike H, Kuroda S, Otsuki S (1996): $\sigma$ receptor antagonists block the development of sensitization to cocaine. Eur J Pharmacol 296:123-128

Ushijima I, Carino MA, Horita A (1995): Involvement of $D_{1}$ and $\mathrm{D}_{2}$ dopamine systems in the behavioral effects of cocaine in rats. Pharmacol Biochem Behav 52:737-741
Van Tol HHM, Bunzow JR, Guan H-C, Sunahara RK, Seeman P, Niznik HB, Civelli O (1991): Cloning of the gene for a human dopamine $\mathrm{D}_{4}$ receptor with high affinity for the antipsychotic clozapine. Nature 350:610-614

Vezina P (1996): $D_{1}$ dopamine receptor activation is necessary for the induction of sensitization by amphetamine in the ventral tegmental area. J Neurosci 16:2411-2420

Vezina P, Stewart J (1989): The effect of dopamine receptor blockade on the development of sensitization to the locomotor activating effects of amphetamine and morphine. Brain Res 499:108-120

Waddington JL, Daly SA (1993): Regulation of unconditioned motor behaviour by $\mathrm{D}_{1}: \mathrm{D}_{2}$ interactions. In Waddington JL (ed), $\mathrm{D}_{1}: \mathrm{D}_{2}$ Dopamine Receptor Interactions. San Diego, CA, Academic Press, pp 51-78

Weiss F, Paulus MP, Lorang MT, Koob GF (1992): Increases in extracellular dopamine in the nucleus accumbens by cocaine are inversely related to basal levels: Effects of acute and repeated administration. J Neurosci 12:43724380

Weiss SRB, Post RM, Pert A,Woodward R, Murman D (1989): Context-dependent cocaine sensitization: Differential effect of haloperidol on development versus expression. Pharmacol Biochem Behav 34:655-661

White FJ, Hu X-T, Henry DJ (1993): Electrophysiological effects of cocaine in the rat nucleus accumbens: Microiontophoretic studies. J Pharmacol Exp Ther 266:10751084

White FJ, Hu X-T, Henry DJ, Zhang X-F (1995a): Neurophysiological alterations in the mesocorticolimbic dopamine system during repeated cocaine administration. In Hammer RP Jr (ed), The Neurobiology of Cocaine: Cellular and Molecular Mechanisms. Boca Raton, FL, CRC Press, pp 95-115

White FJ, Hu X-T, Zhang X-F, Wolf ME (1995b): Repeated administration of cocaine or amphetamine alters neuronal responses to glutamate in the mesoaccumbens dopamine system. J Pharmacol Exp Ther 273:445-454

White FJ (1996): Synaptic regulation of mesocorticolimbic dopamine neurons. Annu Rev Neurosci 19:405-436

White FJ, Hu X-T, Zhang X-F (1998): Neuroadaptations in nucleus accumbens neurons resulting from repeated cocaine administration. In Goldstein D, Eisenhofer G, McCarty R (eds), Catecholamines: Bridging Basic Science with Clinical Medicine. San Diego, CA, Academic Press, pp. 1006-1009

White FJ, Hu X-T (1993): Electrophysiological correlates of $\mathrm{D}_{1}: \mathrm{D}_{2}$ interactions. In Waddington JL (ed), $\mathrm{D}_{1}: \mathrm{D}_{2}$ Dopamine Receptor Interactions. San Diego, CA, Academic Press, pp 79-114

White FJ, Wolf ME (1991): Psychomotor stimulants. In Pratt JA (ed), The Biological Basis of Drug Tolerance and Dependence. London, Academic Press, pp 153-197

Wise RA, Bozarth MA (1987): A psychomotor stimulant theory of addiction. Psychol Rev 94:469-492

Wolf ME, Jeziorski M (1993): Coadministration of MK-801 with amphetamine, cocaine or morphine prevents rather than transiently masks the development of behavioral sensitization. Brain Res 613:291-294 